\title{
MANUSKRIP LA GALIGO DALAM TRADISI MASSURE' DI WAJO-SULAWESI SELATAN
}

\author{
THE LA GALIGO MANUSCRIPT IN THE MASSURE \\ TRADITION IN WAJO-SOUTH SULAWESI
}

\author{
Hamsiati $^{1}$, Wardiah Hamid ${ }^{2}$, Mustolehudin ${ }^{3}$ \\ ${ }^{123}$ Badan Penelitian dan Pengembangan dan Pendidikan dan Pelatihan \\ Kementerian Agama Republik Indonesia \\ hamsiatib@gmail.com
}

DOI: $10.31291 / j \mathrm{lk.v19i1.906}$

Diterima: 24 Februari 2021; Direvisi: 16 Juni 2021; Diterbitkan: Juni 2021

\begin{abstract}
The La Galigo Manuscript is the longest literary work in the world, which is the ancestral heritage of the people of South Sulawesi. These manuscripts contain knowledge, traditions, religion, and art. This paper aims to explore the La Galigo manuscript in the massure' tradition in Wajo. Methods of collecting data through interviews, observation, and documentation. The findings show that the existence of the La Galigo manuscript in Wajo is partly a private collection of the community. This manuscript, in the context of socio-religious culture, is practiced through the massure art tradition by the Bugis Wajo community. The Massure' tradition can be found in Bugis community ceremonies such as the maddoja bine tradition, mappenre' tojang, menre' bola baru (rising to a new house), tudang penni (pre-wedding night party), and cultural festivals in Wajo.
\end{abstract}

Keywords: La Galigo, Manuscript, Massure', Wajo

\section{ABSTRAK}

Manuskrip La Galigo merupakan karya sastra terpanjang di dunia, yang merupakan warisan nenek moyang masyarakat Sulawesi Selatan. Manuskrip ini memuat tentang pengetahuan, tradisi, agama dan kesenian. Tulisan ini bertujuan mengeksplorasi manuskrip La Galigo dalam tradisi massure' di Wajo. Metode pengumpulan data melalui wawancara, observasi dan dokumentasi. Hasil temuan menunjukkan keberadaan manuskrip La Galigo di Wajo sebagian merupakan koleksi pribadi masyarakat. Manuskrip ini 
dalam konteks sosial budaya keagamaan, dipraktikkan melalui tradisi kesenian massure' oleh masyarakat Bugis Wajo. Tradisi Massure' dapat dijumpai pada upacara-upacara masyarakat Bugis seperti dalam tradisi maddoja bine, mappenre' tojang, menre' bola baru (naik rumah baru), tudang penni (pesta malam pra akad nikah), dan festival kebudayaan di Wajo.

Kata Kunci: La Galigo, Manuskrip, Massure’, Wajo

\section{PENDAHULUAN}

Tradisi Massure' merupakan sebuah tradisi kesenian yang mengiringi pembacaan manuskrip La Galigo. Tradisi lisan (membaca) manuskrip La Galigo di Wajo Sulawesi Selatan masih dilestarikan oleh passure' (pembaca) da tetua adat hingga saat ini dalam beberapa ritual keagamaan. Tradisi tersebut menarik untuk diteliti secara mendalam dan dipublikasikan secara luas agar dapat diketahui masyarakat Sulawesi khususnya sebagai bentuk penghormatan dan sebagai upaya pelestarian budaya lokal.

Manuskrip La Galigo di Bugis telah diakui dunia internasional oleh United Nations Educational Scientific and Cultural Organization (UNESCO) sebagai "Memory of the World" pada tahun 2011, ${ }^{1}$ akan tetapi tidak banyak orang Indonesia yang mengetahui tentang manuskrip La Galigo. Di Sulawesi Selatan sendiri, nama La Galigo terbilang cukup familiar karena dipakai menjadi nama jalan atau kafe. Epik La Galigo merupakan manuskrip yang terdiri dari ribuan halaman dan berisi tentang kisah-kisah yang menarik. Koolhof ${ }^{2}$ dan Kern, ${ }^{3}$ menempatkannya sebagai karya sastra terpanjang di dunia. Manuskrip ini

${ }^{1}$ Achmad Zulfikar, "Internalisasi Nilai-Nilai Sastra I La Galigo Dalam Forum Internasional," in Kongres Internasional II Bahasa-Bahasa Daerah Sulawesi Selatan Tahun 2012 (Sulawesi Selatan: Balai Bahasa Provinsi Sulawesi Selatan dan Provinsi Sulawesi Barat, 2017), 1-12, https://doi.org/ 10.31227/osf.io/p6sh7.

${ }^{2}$ Sirtjo Koolhof, Dutana Sawerigading: Een Scene Uit de I La Galigo (Belanda: Universitas Leiden, 1992).

${ }^{3}$ R.A. Kern, Catalogus van de Boeginise, Tot de I Lagaligo-Cyclus Behorende Handschriften van Jajasan Matthes (Matthesstichting) Te Makassar (Indonesie (Makassar: Jajasan Matthes, 1954). 
mengalahkan epik India Mahabarata dan Ramayana serta epik Yunani Homerus. ${ }^{4}$ Manuskrip La Galigo memiliki 6000 halaman dan 250.000 kata dalam perbendaharaan sastra La Galigo.

Manuskrip pada dasarnya merupakan refleksi budaya masa lalu yang dapat diterapkan pada masa sekarang. ${ }^{5}$ Informasi yang terdapat dalam manuskrip tidak hanya dapat difungsikan oleh generasi saat ini, tetapi juga dapat bermanfaat untuk generasi yang akan datang. ${ }^{6}$ Informasi tentang rentetan kisah yang terdapat dalam manuskrip La Galigo, ${ }^{7}$ yang mengekspresikan tentang tradisi, agama, dan kesenian, akan sangat disayangkan jika tidak sampai diketahui oleh generasi yang akan datang.

Studi terhadap manuskrip La Galigo dalam rangka mengapresiasi dinamika teks-teks Bugis, penting diteliti untuk melihat "dinamika teks" yang mengungkapkan hubungan manuskrip dan kebudayaan suatu masyarakat. Manuskrip La Galigo secara khusus menunjukkan kedudukan (fungsi) manuskrip dalam upacara/ ritual. Upacara yang dimaksudkan adalah aktivitas masyarakat yang didasari oleh solidaritas keagamaan. Oleh karena itu, manuskrip yang terkait dengan upacara itu adalah manuskrip yang berdimensi keagamaan yang berperan penting dalam transmisi intelektual pada masa lalu. ${ }^{8}$

Manuskrip La Galigo mewariskan sejumlah tradisi yang saling berkaitan satu sama lain dengan berbagai upacara yang sakral. Semua upacara diiringi dengan berbagai kesenian dan pembacaan episode La Galigo yang episodenya disesuaikan

\footnotetext{
${ }^{4}$ Nurhayati Rahman, “Agama, Tradisi Dan Kesenian Dalam Manuskrip La Galigo,” Jurnal Sari (ATMA) 26 (2008): 213-20.

${ }^{5}$ Khairil et. all Anwar, Manuskrip Klasik Keagamaan Edisi Bahasa Melayu (Tangerang: CV. Sejahtera Kita, 2009).

${ }^{6}$ Yunus Winoto, "Membangun Kesadaran Masyarakat Sumedang dalam Melestarikan Warisan Budaya (Sebuah Kajian Fenomenologis Tentang Pengalaman Pustakawan Perpustakaan Yayasan Pangerang Sumedang Dalam Melakukan Kegiatan Pelestarian Buku 'Babad Sumedang')," LIBRARIA: Jurnal Perpustakaan 6, no. 1 (2018): 83-110, https://doi.org/http://dx.doi.org/ 10.21043/libraria.v6i1.3891. Galigo."

${ }^{7}$ Rahman, "Agama, Tradisi Dan Kesenian Dalam Manuskrip La

${ }^{8}$ Oman Fathurahman, Filologi Indonesia Teori Dan Metode (Jakarta: Kencana, 2015).
} 
dengan upacara yang berlangsung. Kesenian yang mengiringinya antara lain massuling lontaraq (meniup suling diiringi nyanyian La Galigo), maggiriq (para bissu menari sambil menusuk badannya dengan badik) séré bissu (joget bissu), mallae-lae, maggenrang (bermain gendang), massureq (membaca La Galigo) dan sebagainya. ${ }^{9}$

Manuskrip La Galigo, juga manuskrip-manuskrip kuno lain di Kabupaten Wajo, memuat berbagai informasi tentang kehidupan sosial budaya masyarakat Sulawesi Selatan. Manuskrip tersebut berisi tentang berbagai gagasan, ide, sistem pengetahuan, akhlak, filsafat, dan agama, saat ini masih dilestarikan oleh sebagian tokoh adat dan masyarakat di Kabupaten Wajo. ${ }^{10}$

Kajian manuskrip baik dari sisi teks atau konteks, sangat penting untuk dilakukan. Perhatian pemerintah terhadap manuskrip kuno di kawasan Indonesia Timur khususnya, sudah dilakukan oleh Balai Litbang Agama Makassar. Berdasarkan inventarisasi dan digitalisasi yang dilakukan lembaga tersebut, ditemukan 440 manuskrip kuno keagamaan yang berisi tentang akhlak, Al-Qur'an, Azimat, bahasa, ceramah, doa, fikih, hadis, tarekat, tasawuf, tauhid, dan zikir. ${ }^{11}$ Kemudian persebaran manuskrip di kawasan Indonesia Timur, sebagaimana dijelaskan dalam Katalog 1 hasil inventarisasi tersebut, terdiri dari 1000 manuskrip keagamaan. ${ }^{12}$

Studi manuskrip kuno di Wajo, telah dilakukan oleh peneliti terdahulu dengan berbagai topik dan pendekatan yang ber-

${ }^{9}$ Nurhayati Rahman, "Edisi Manuskrip-Manuskrip Bugis," in Direktori Edisi Manuskrip Nusantara, ed. ES Ekajati (Jakarta: Masyarakat Permanuskripan Nusantara-Yayasan Obor Indonesia, 2000).

${ }^{10}$ Wiwik et al Pertiwi, Kajian Nilai Budaya Manuskrip Kuna Mapalina Sawerigading Ri Saliweng Langi (Jakarta: Direktorat Jenderal Kebudayaan RI, 1998). 2018).

${ }^{11}$ Idham, Katalog Manuskrip Keagamaan (Jakarta: Litbangdiklat Press,

${ }^{12}$ Abd Kadir et. al Masoweang, Katalog 1 Manuskrip Keagamaan Kawasan Timur Indonesia (Makassar: Balai Penelitian dan Pengembangan Agama Makassar, 2015). 
beda-beda. Kajian yang dilakukan Nurnaningsih, ${ }^{13}$ menjelaskan bahwa manuskrip Lontaraq Galigo memuat petuah raja-raja dan orang bijak Bugis. Isi dari teks tersebut berisi tentang normanorma sosial dan budaya kenegaraan, keagamaan, perekonomian, seni, hukum, dan politik. Kajian lain yang serupa dengan tulisan ini adalah studi yang dilakukan Fachruddin Ambo. Dalam temuan penelitiannya, dijelaskan tentang kisah Sawerigading berlayar ke tanah Cina dengan menumpangi perahu milik Walenreng yang mempunyai kandungan makna budaya yang penuh misteri dalam kepercayaan masyarakat Bugis pada masa lampau. ${ }^{14}$ Tulisan lain mengenai naskah-naskah di Wajo ditulis Husnul Fahimah Ilyas yang hasilnya menjelaskan Islamisasi di Wajo dalam manuskrip Lontaraq Suqkuna Wajo, sebuah kronik terlengkap dari Lontara' Wajo, selain juga memuat riwayat kerajaan di Sulawesi Selatan khususnya Wajo. ${ }^{15}$

Sarjana Barat yang telah mengkaji manuskrip La Galigo di antaranya adalah Benjamin Frederik Matthes. ${ }^{16}$ Ia merupakan ilmuwan pertama yang meneliti manuskrip ini. Matthes merupakan perwakilan Nederlandsch Bijbelgenootschap untuk Daerah Sulawesi Selatan pada tahun 1847. Selanjutnya ilmuwan lain yang meneliti manuskrip La Galigo adalah Arung Pancana Toa, ${ }^{17}$ yang menulis manuskrip NBG 188, dan Andi Zainal Abidin yang menulis tentang siklus epik La Galigo yang merupakan karya

\footnotetext{
${ }^{13}$ Nurnanigsih, "Asimilasi Lontara Pangadereng Dan Syariat Islam : Pola Perilaku Masyarakat Bugis-Wajo," Al-Tahrir: Jurnal Pemikiran Islam 15, no. 1 (2015): 21, https://doi.org/10.21154/al-tahrir.v15i1.168.

${ }^{14}$ Fachruddin Ambo Enre, Ritumpanna Welenrennge. Telaah Filologis Sebuah Episode Sastera Bugis Klassik Galigo (Jakarta: Universitas Indonesia, 1983).

${ }^{15}$ Nurnaningsih, "Rekonstruksi Falsafah Bugis Dalam Pembinaan Karakter: Kajian Manuskrip Paaseng Toriolo Tellumpoccoe," Jurnal Lektur Keagamaan 13, no. 2 (2015): 393, https://doi.org/10.31291/jlk.v13i2.232.

${ }^{16}$ Benjamin Frederik Matthes, De Makassaarsche En Boeginesche Kotika's (Gravenhage: martinus Nijhoff, 1875), https://opac.perpusnas.go.id/ DetailOpac.aspx?id=602396.

${ }^{17}$ Arung Pancana Toa, La Galigo Menurut Manuskrip NBG 188 Edisi Kedua Jilid I, ed. fachruddin Ambo Enre (Jakarta: Yayasan Obor Indonesia, Yayasan La Galige, KITLV, 2017).
} 
sastra dalam bentuk puisi yang ditulis dalam bahasa Bugis Kuno. $^{18}$

Sarjana Indonesia yang menekuni manuskrip La Galigo salah satunya Nurhayati Rahman, ${ }^{19}$ di antara karya-karyanya adalah edisi manuskrip-manuskrip Bugis, cinta, laut dan kekuasaan dalam epos La Galigo, sejarah dan dinamika perkembangan huruf lontaraq di Sulawesi Selatan. Kemudian sarjana lain yang mendalami manuskrip Bugis di antaranya: Mukhlis Paeni, ${ }^{20}$ Pudentia, ${ }^{21}$ Campbell Macknight, ${ }^{22}$ dan lainnya. Manuskrip La Galigo mempunyai struktur cerita yang besar, yang di dalamnya terdapat berbagai cerita yang dapat dikate-gorikan sebagai subcerita ataupun episode. Setiap episode dapat disaksikan dalam dua dimensi, di satu sisi sebagai bagian dari konstruksi La Galigo secara keseluruhan, di sisi lain sebagai cerita independen. Dengan kata lain, La Galigo memiliki satu alur cerita besar yang terdiri dari beberapa episode. Setiap episodenya juga memiliki plotnya masing-masing, yang sebenar-nya merupakan sub-plot dari La Galigo secara keseluruhan. ${ }^{23}$

Studi lain tentang manuskrip La Galigo juga dilakukan Andi Perdana. ${ }^{24}$ Studi Andi Perdana lebih menitikberatkan pada aspek identitas budaya lokal Sulawesi Selatan. Dalam kajian lainnya, ${ }^{25}$ Andini Perdana menjelaskan tentang keterkaitan ma-

${ }^{18}$ Andi Zainal Abidin, "The I La Galigo Epic Cycle Of South Celebes And Its Diffusion,” JSTOR 53, no. 17 (1974): 161-69, https://www.jstor.org/ stable/3350778?seq=1.

${ }^{19}$ Rahman, "Edisi Manuskrip-Manuskrip Bugis."

${ }^{20}$ Mukhlis Paeni, Sejarah Kebudayaan Indonesia; Religi Dan Falsafah (Jakarta: PT Raja Grafindo Persada, 2009).

${ }^{21}$ Pudentia Maria Purenti Sri Suniarti Karnadi, "Mak Yong: Hakikat Dan Proses Penciptaan Kelisanan” (Universitas Indonesia, 2000), http://lib.ui. ac.id/detail?id=74091\&lokasi=lokal.

${ }^{22}$ Campbell Macknight, "'I La Galigo': State Theatre, Melbourne International Arts Festival 19-23 October 2006," Jurnal RIMA: Review of Indonesian and Malaysian Affairs 40, no. 2 (2006): 1-152.

${ }^{23}$ Toa, La Galigo Menurut Manuskrip NBG 188 Edisi Kedua Jilid I.

${ }^{24}$ Andini Perdana, "La Galigo Identitas Budaya Sulawesi Selatan Di Museum La Galigo," Pangadereng : Jurnal Hasil Penelitian Ilmu Sosial Dan Humaniora 5, no. 1 (2019): 116-32, https://doi.org/10.36869/.v5i1.16.

${ }^{25}$ Andini Perdana, "Nilai Budaya Manuskrip La Galigo Dan Perahu Pinisi Di Museum Untuk Generasi Milenial," Walasuji : Jurnal Sejarah Dan 
nuskrip La Galigo dan perahu pinisi. Hal ini menggambarkan bahwa nenek moyang orang Sulawesi selain sebagai pelaut, mereka juga sangat menghormati dan menjaga nilai-nilai budaya seperti yang dijelaskan dalam manuskrip La Galigo. Pada masa kini, salah satu bentuk pelestarian manuskrip La Galigo yang dilakukan adalah mengenalkan kepada generasi milenial. Studi yang dilakukan Asrullah Ahmad, ${ }^{26}$ terhadap manuskrip La Galigo yang berisi tentang kepahlawanan dan kekuasaan para dewa, dikonstruksikan ke dalam sebuah buku cerita bergambar, sehingga dapat menarik minat anak-anak khususnya di Sulawesi.

Kajian-kajian lain yang menguatkan penelitian ini salah satunya dilakukan Donald Qomaidiansyah. ${ }^{27}$ Studi yang dilakukan Donald, menunjukkan bahwa pengaruh Islam diawali dari jaringan perdagangan di kawasan Laut Sulawesi, bagi pedagang yang menghubungkan ke Maluku sebagai satu pola Islamisasi. Jaringan ini memberi dampak terhadap perubahan sosial di Bolaang Mongondow Utara yang terjadi pada abad ke-17-19 M. Demikian pula kajian Gayda Bachmid, ${ }^{28}$ terhadap kitab al Barzanji di Sulawesi Utara, menjadi media terwujudnya nilainilai Islam yang mengusung tema-tema kultural.

Berlimpahnya manuskrip-manuskrip kuno di Sulawesi dan kawasan Indonesia Timur lainnya, menjadi penanda bahwa literatur-literatur keislaman tersebut masih belum banyak dilakukan penelitian, terutama dari aspek isi manuskrip. Kajian yang

Budaya 11, no. 1 (2020), https://doi.org/https://doi.org/10.36869/ wjsb. v11i1.72.

${ }^{26}$ Ahmad Asrullah, "Perancangan Buku Cerita Bergambar Berjudul Sawerigading Dari Cerita Rakyat Manuskrip Kuno 1 La Galigo" (Universitas Komputer Indonesia, 2016), http://elib.unikom.ac.id/gdl.php?mod= browse \&op=rea.

${ }^{27}$ Donald Qomaidiansyah Tungkagi, "Islam Di Bolaang Mongondow Utara, Sulawesi Utara: Dinamika Islamisasi Di Kerajaan Kaidipang Besar Dan Bintauna Abad Ke-7-19 M," Jurnal Lektur Keagamaan 17, no. 2 (2019): 461-500, https://doi.org/https://doi.org/10.31291/jlk.v17i2.747.

${ }^{28}$ Gayda Bachmid, "Kitab ' Barzanji ' Dalam Perspektif Masyarakat Muslim Di Manado, Sulawesi Utara," Lektur Keagamaan 12, no. 2 (2014): 419-40, https://doi.org/https://doi.org/10.31291/jlk.v12i2.42. 
dilakukan Mustari, ${ }^{29}$ menjadi bukti bahwa kajian manuskrip kuno dalam teks Lontaraq yang mengkaji tentang gender masih sangat jarang, seperti Lontaraq Sitti Rabiatul Alawiya yang tersimpan di Perpustakaan Arsip nasional RI Cabang Makassar. Teks ini berisi tentang perlawanan gender dari seorang perempuan soliter bernama Sitti Rabiatul Alawiyah di tengah-tengah paham patriarki. Penelitian-penelitian terhadap upaya pelestarian manuskrip kuno di Sulawesi Selatan sejatinya sudah dilakukan oleh Balai Litbang Agama Makassar dan juga Badan Arsip dan Perpustakaan Provinsi Sulawesi Selatan, melalui inventarisasi dan digitalisasi manuskrip.

Penelitian-penelitian tersebut di atas, menjadi dasar bahwa studi manuskrip di Sulawesi dan kawasan Indonesia Timur menjadi pintu pembuka intelektual keislaman di wilayah tersebut. Studi tentang manuskrip La Galigo dari perspektif seni budaya keagamaan, dapat menjadi penyumbang khazanah keilmuan dan dapat melengkapi penelitian-penelitian sebelumnya yang dilakukan peneliti terdahulu. Praktik tradisi seni yang dilakukan masyarakat Makassar, termasuk dalam ritual pembacaan manuskrip sastra La Galigo, tidak menggunakan puik-puik (bunyi-bunyian yang ditiup) dan dimainkan bersama sepasang gandrang. ${ }^{30}$ Kajian yang dilakukan Hudzaifah ini, memfokuskan aspek seni gandrang yang diiringi puik-puik. Seni yang terkandung dalam manuskrip La Galigo, memiliki nilai-nilai religi yang disimbolkan dengan Bhatara Guru yang dikatakan sebagai entitas awal dari Suku Bugis dan sekaligus diyakini sebagai raja pertama di Kerajaan Luwu. ${ }^{31}$

Penelitian ini merupakan penelitian kualitatif. Kajian konteks manuskrip La Galigo difokuskan pada tradisi massure’ di

${ }^{29}$ Mustari, "Perlawanan Gender Dalam Manuskrip Klasik Keagamaan Bugis Kasus Lontaraq Sitti Rabiatul Awwaliya," Jurnal Lektur Keagamaan 5, no. 2 (2007): 159-82.

${ }^{30}$ Adiatma Hudzaifah, "Peran Puik-Puik Dalam Kesenian Gandrang Makassar," Dewa Ruci: Jurnal Pengkajian Dan Penciptaan Seni 15, no. 2 (2020): 101-9, https://doi.org/10.33153/dewaruci.v15i2.2699.

${ }^{31}$ Hudzaifah.’Peran Puik-Puik dalam Kesenian Gandrang Makassar,'. 
Kabupaten Wajo. ${ }^{32}$ Manuskrip yang menjadi objek penelitian adalah manuskrip Sure' Selleang (La Galigo) episode Mammusuna Karaeng Tompo" Sibawa La Galigo koleksi Dauleng yang bertempat tinggal di Desa Baru Alau, Kecamatan Tempe Kabupaten Wajo. Manuskrip klasik atau sure' yang menjadi koleksi Ibu Dauleng yang menjadi fokus dalam penelitian ini merupakan bagian manuskrip La Galigo yang bagian episodenya atau terengnya membahas tentang Peperangan antara Karaeng Tompo melawan La Galigo.

Kajian ini dilakukan dengan menggunakan perangkat filologi sebagai alat bantu untuk melakukan kajian mendalam mengenai kebudayaan dan sejarah intelektual. Manuskrip La Galigo dan tradisi massure' menjadi fokus penelitian dalam tulisan ini. Berpijak dari latar belakang tersebut, permasalahan penelitian ini adalah bagaimana sejarah keberadaan manuskrip dan persebarannya sampai sekarang, dan bagaimana hubungan manuskrip dengan tradisi massure' di Kabupaten Wajo?

Sumber data dalam penelitian ini adalah berupa tinggalan budaya, baik berupa tulisan maupun benda, dokumen, dan tradisi lisan. Penjaringan data dalam penelitian ini, dilakukan melalui wawancara mendalam dengan informan kunci, observasi ritual atau acara keagamaan yang menggunakan teks manuskrip. Untuk menelaah manuskrip yang berkaitan dengan ritual keagamaan, dalam penelitian ini menggunakan pendekatan inter-disipliner. ${ }^{33}$ Pertama, dengan menggunakan teori filologi. ${ }^{34}$ Teori ini digunakan untuk mengetahui keberadaan manuskrip, seluk beluk manuskrip, kondisi manuskrip, kodikologi, dan isi manuskrip. ${ }^{35}$

${ }^{32}$ Anonim, Manuskrip Sure’ Selleang (Manuskrip La Galigo) Episode: Mammusuna Karaeng Tompo’ Sibawa La Galigo, Koleksi Dauleng Di Baru Alau Kec. Tempe Kab. Wajo., n.d.

${ }^{33}$ Setya Yuwana Sudikan, "Pendekatan Interdisipliner, Multidisipliner, Dan Transdisipliner Dalam Studi Sastra," Paramasastra: Jurnal Ilmiah Bahasa Sastra Dan Pembelajarannya 2, no. 1 (2015): 68-70, https://doi.org/http://dx.doi.org/10.26740/parama.v2n1.p\%25p.

${ }^{34}$ Siti Baroroh Baried, Pengantar Filologi (Jakarta: Departemen Pendidikan dan Kebudayaan, 1985).

${ }^{35}$ Oman Fathurahman, Filologi Dan Islam Indonesia (Jakarta: PUSLITBANG Lketur dan Khazanah Keagamaan dan Manajemen Organisasi Badan LITBANG dan DIKLAT Kementerian Agama RI, 2010). 
Kedua, menggunakan pendekatan studi sejarah sosial ${ }^{36}$ yang bertujuan untuk mengetahui konteks latar belakang munculnya teks dan keberadaan manuskrip yang dikaji. Pendekatan sejarah sosial intelektual dengan memosisikan manuskrip sebagai faktor sosial intelektual yang turut menentukan sebuah perjalanan sejarah. ${ }^{37}$ Menurut Azra, ${ }^{38}$ perpaduan antara pendekatan filologi dengan sejarah sosial intelektual memberi kontribusi yang besar bagi dunia sejarah Nusantara. Ketiga, pendekatan antropologi yang digunakan untuk mengetahui perkembangan budaya saat ini dan relevansinya dengan kontekstual dan upacara keagamaan dalam masyarakat di mana manuskrip itu hidup. ${ }^{39}$

\section{HASIL DAN PEMBAHASAN}

\section{Wajo dan Manuskrip La Galigo}

Nama Wajo berasal dari kata Bajo, sebutan bagi pohon besar yang kokoh dengan daun yang rimbun dan rindang yang menjadi tempat berteduh bagi para pelancong dan pemburu. Kemudian seiring berjalannya waktu, pengucapan Bajo berubah menjadi Wajo, yang dari sinilah asal muasal nama Wajo. ${ }^{40} \mathrm{Kabu}-$ paten Wajo, dengan ibukotanya Sengkang, terletak di bagian tengah provinsi Sulawesi Selatan, sekitar $250 \mathrm{~km}$ dari Kota Makassar, ibu kota provinsi Sulawesi Selatan. ${ }^{41}$

Hasil karya intelektual masa lalu berupa tulisan-tulisan yang kini menjadi manuskrip kuno telah menjadi harta tak ternilai bagi Kabupaten Wajo. Salah satu yang terkenal adalah manuskrip La Galigo. Manuskrip asli La Galigo, yang terdiri dari 13 jilid, berada di perpustakaan Universitas Leiden, yang

${ }^{36}$ Akh Minhaji, Sejarah Sosial Dalam Studi Islam, Teori, Metodologi, Dan Implementasi (Yogyakarta: Suka Press, 2010). 2003)

${ }^{37}$ Kuntowijoyo, Metodologi Sejarah (Yogyakarta: Tiara Wacana,

${ }^{38}$ Azyumardi Azra', Jaringan Ulama Timur Tengah Dan Kepulauan Nusantara Abad XVII \& XVII (Jakarta: Prenada Media Group, 2005).

${ }^{39}$ Clifford Geertz, Agama Jawa Abangan, Santri, Priyayi Dalam Kebudayaan Jawa, ed. Moh Zaki (Depok: Komunitas Bambu, 2014).

${ }^{40}$ Toa, La Galigo Menurut Manuskrip NBG 188 Edisi Kedua Jilid I.

${ }^{41}$ Provinsi Sulawesi Selatan, "Deskripsi Daerah Kabupaten Wajo," https://sulselprov.go.id/pages/des_kab/21, 2007. 
menyimpan 12 jilid, sedangkan 1 jilid naskah ini tersimpan di Museum Makassar. Walaupun sebagian besar berada di Leiden, namun saat ini manuskrip tersebut dapat diakses via online oleh siapapun dan kapanpun.

Manuskrip La Galigo, demikian masyarakat Bugis menyebutnya, bila menyangkut tulisan yang terkandung dalam ribuan manuskrip, kini tersebar di berbagai perpustakaan di dalam dan luar negeri, atau yang fragmen episode-episodenya di simpan oleh beberapa masyarakat Bugis yang setia menjaga dan merawatnya. Sebaliknya, bila hanya menyebut Galigo berarti lagu-lagu atau tembang-tembang dari manuskrip La Galigo, yang dinyanyikan dengan ritme tetap dan datar selama upacara ritual. Kemudian dinamakan Maggaligo yang artinya melagukan manuskrip La Galigo, sedangkan Paggaligo artinya orang yang menembangkan atau sang penembang. Adapun, jika hanya menyebut I La Galigo, itu berarti nama karakter dalam manuskrip La Galigo. ${ }^{42}$

Manuskrip La Galigo merupakan manuskrip kuno peninggalan masyarakat Bugis. ${ }^{43}$ Manuskrip ini merupakan mitologi sistematika yang dijelaskan dalam bahasa sastra dengan penekanan pada bagian akhir, sehingga karya tersebut lebih penting sebagai karya sastra daripada karya antropologis. ${ }^{44}$ Manuskrip yang terdiri kurang lebih 6000 halaman ini mempunyai kandungan cerita yang terdiri dari rentetan episode. Beberapa sumber menyebutkan bahwasanya Episode La Galigo diawali dengan kisah manusia pertama di muka bumi (mula tau) dan keturunannya menggunakan bahasa indah yang berbeda dengan bahasa Bugis pada umumnya, terutama dalam istilah leksikal. ${ }^{45}$

${ }^{42}$ Nurhayati Rahman, La Galigo, Menelusuri Jejak Warisan Sastra Dunia (Makassar: Pusat Studi La Galigo Divisi Ilmu Sosial dan Humaniora Pusat Kegiatan Penelitian Universitas Hasanuddin dengan Pemerintah Kabupaten Barru, 2003).

${ }^{43}$ Rahman. La Galigo, Menelusuri Jejak Warisan Sastra Dunia,'.

${ }^{44}$ Kern, Catalogus van de Boeginise, Tot de I Lagaligo-Cyclus Behorende Handschriften van Jajasan Matthes (Matthesstichting) Te Makassar (Indonesie.

${ }^{45}$ Enre, Ritumpanna Welenrennge. Telaah Filologis Sebuah Episode Sastera Bugis Klassik Galigo. 
Selain itu juga mengisahkan tentang kehidupan dunia atas, dunia tengah, dan dunia bawah yang salah satu tokoh utamanya adalah Sawerigading. Nama Sawerigading selalu ada di setiap episode La Galigo.

Sureq Galigo atau sure' selleang (nama lain manuskrip La Galigo) tidak berada dalam satu manuskrip sekaligus. Setiap manuskrip yang ada berisi satu atau dua episode atau tereng (istilah Bugis) yang sebenarnya bisa ditautkan ke episode lain di manuskrip lain. Sureq Galigo dicirikan oleh ritme atau mentrumnya: setiap segmen terdiri dari empat atau lima suku kata. ${ }^{46}$ Berikut ini salah satu contoh manuskrip La Galigo yang ditulis dalam huruf Lontaraq. Secara filologis, manuskrip ini merupakan koleksi Dauleng. Kondisi manuskrip masih cukup baik, dengan ukuran 23 x $16 \mathrm{~cm}$. Aksara dalam manuskrip ini adalah huruf lontaraq dengan bahasa Bugis. Dalam manuskrip ini tidak diketahui penyalin dan tahun penyalinan.
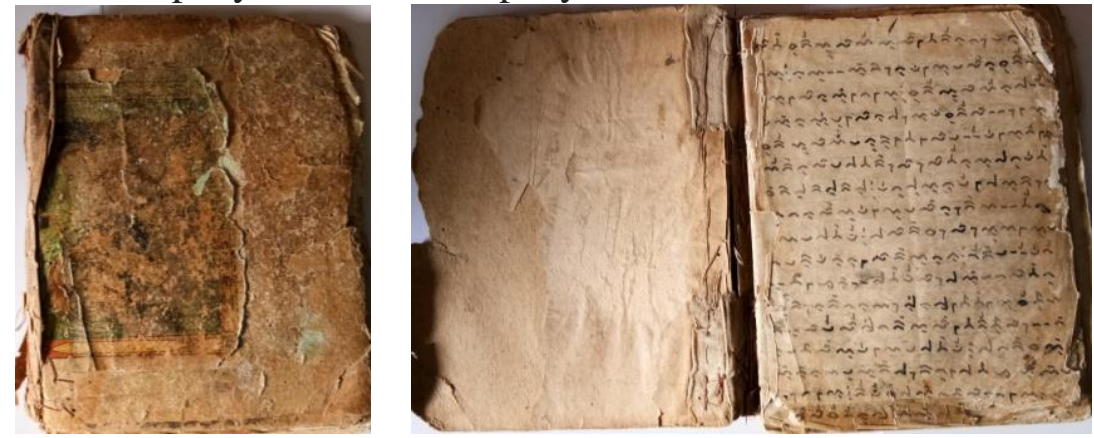

Gambar 1.

Sumber: Dokumentasi Pribadi Penulis

Manuskrip Sure’ Selleang (Manuskrip La Galigo)

Koleksi Dauleng

\section{Sejarah Keberadaan Manuskrip}

Keberadaan manuskrip La Galigo di Wajo menjadi koleksi pribadi sebagian kecil masyarakat yang disimpan di rumah masing-masing. Kesadaran masyarakat akan pentingnya memelihara manuskrip tersebut, membuat manuskrip masih dapat dite-

${ }^{46}$ Enre. Enre, Ritumpanna Welenrennge. Telaah Filologis Sebuah Episode Sastera Bugis Klassik Galigo 
mui hingga saat ini. Namun, tak jarang di antara sebagian masyarakat menyembunyikan keberadaan manuskrip. Mereka pada umumnya beranggapan bahwasanya manuskrip kuno atau sure' tersebut adalah pusaka keluarga, sehingga manuskrip tersebut hanya akan dikeluarkan pada saat-saat tertentu setelah mereka menyiapkan sesajian. Ketakutan akan direbutnya manuskrip dari tangan mereka oleh saudara yang lain atau dari pihak pemerintah membuat mereka enggan untuk memberitahukan keberadaan manuskrip. Di sisi lain, mereka meyakini bahwasanya manuskrip atau sure' tersebut adalah benda yang sakral, yang tidak seharusnya diletakkan di sembarang tempat atau diperlihatkan kepada orang lain yang belum mereka percaya, karena hal tersebut akan mendatangkan mudharat.

Proses pewarisan manuskrip La Galigo yang menjadi koleksi masyarakat di Wajo, dilakukan melalui beberapa tahap. Pertama, pada umumnya manuskrip diperoleh dari nenek moyang secara turun temurun dari keluarga, sehingga membuat mereka memelihara manuskrip dengan menyimpannya di tempat penyimpanan khusus dan membungkusnya dengan kain putih. Manuskrip tersebut akan dikeluarkan dari tempatnya pada waktu-waktu tertentu atau pada saat manuskrip itu dibutuhkan. Mereka tidak sembarangan dalam memperlihatkan manuskrip tersebut kepada orang lain. Manuskrip ini dikoleksi oleh masyarakat tertentu (seperti; tokoh adat, passure', budayawan, dan juga filolog).

Kedua, proses pewarisan diperoleh dari masyarakat umum (yang memiliki manuskrip) yang diserahkan kepada tetua adat, passure', filolog, maupun budayawan yang dapat membaca manuskrip Lontaraq (manuskrip La Galigo). Masyarakat yang telah menyadari kandungan dari manuskrip tersebut, secara sadar akan menyerahkan kepada orang atau lembaga yang lebih tepat untuk mengkaji kandungan teks manuskrip tersebut, sehingga ilmu pengetahuan yang terdapat di dalamnya pun bisa diketahui dan dimanfaatkan oleh masyarakat luas. Mereka sadar bahwasanya dari pada manuskrip kuno tersebut dipusakakan, lebih baik dipustakakan (untuk dapat dimanfaatkan oleh masyarakat umum) (Wawancara dengan Sudirman, 11-8-2020). Manuskrip ini biasanya diberikan kepada budayawan atau filolog. 
Ketiga, Proses pewarisan yang diperoleh dari masyarakat yang mempunyai profesi tertentu yang berkaitan dengan manuskrip La Galigo. Seperti passure' (orang yang membacakan manuskrip La Galigo dengan irama unik). Passure' pada umumnya memperoleh manuskrip dari nenek atau ibu yang berprofesi sebagai passure' atau dari koleganya. Dari beberapa passure' yang ditemui, pada umumnya koleksi manuskrip mereka diperoleh dari nenek, ibu, atau koleganya yang seprofesi sebagai passure'. Mereka akan menggunakan manuskrip tersebut ketika mereka diundang oleh masyarakat untuk membaca sure' pada waktu-waktu tertentu. Passure' Indo Masse' sang maestro (75 Tahun) memperoleh salinan manuskrip dari masyarakat Tolotang di Buloe-Wajo. Beliau diberikan manuskrip untuk disalin karena beliau disenangi oleh salah satu masyarakat Tolotang caranya melantunkan La Galigo. Lalu ia salin dan pelajari lebih lanjut dan terus melantunkannya hingga kini.

Koleksi manuskrip milik Indo Masse' membahas episode Riwayat pertama manusia di bumi (mula tau) (Wawancara dengan Indo Masse,11-8-2020). Passure' Dauleng (75 tahun) memperoleh manuskrip dari neneknya yang bernama Baweng yang juga berprofesi sebagai passure'. Beliau tertarik untuk membaca sure' sejak kecil. Ketika neneknya pulang dari acara massure', sure' neneknya akan diambil lalu dipelajari cara membacanya. Terkadang ia akan dikoreksi oleh neneknya ketika mendapatkan kesalahan dalam membaca (Wawancara dengan Dauleng, 30-8-2020). Ibu Dauleng (75 tahun) adalah salah satu passure' Wajo yang sudah sepu (tua), namun semangatnya untuk melantunkan La Galigo tak pernah surut. Manuskrip ini diperoleh dari neneknya yang bernama Baweng. Dia tinggal di Lingkungan Baru Alau Desa Laelo Kecamatan Tempe Kabupaten Wajo. 


\section{Pembacaan Manuskrip La Galigo melalui Tradisi Massure' di Wajo.}

Kajian ilmiah tentang aspek La Galigo dapat dipetakan ke dalam dua bagian, yaitu aspek tulisan dan aspek lisan. ${ }^{47}$ Aspek tulisan mencakup manuskrip La Galigo tersebut baik dari segi teks, dan kandungan. Kajian aspek tulisan La Galigo saat ini, telah banyak ditemukan baik berupa transliterasi, terjemahan ataupun kandungan makna teks. Adapun kajian aspek lisan yang merupakan kajian konteks dari manuskrip La Galigo tersebut masih perlu dikenalkan lebih jauh kepada masyarakat umum. Seperti alih manuskrip menjadi cerita bergambar dan menjadi daya tarik bagi generasi muda masa kini. Demikian juga melalui tradisi lisan manuskrip La Galigo melalui pembacaan teks manuskrip. Manuskrip La Galigo biasanya tidak dibaca dengan hati atau sendiri tetapi dinyanyikan oleh seseorang untuk penonton yang hadir. ${ }^{48}$ Hal ini dikenal oleh masyarakat Bugis dengan tradisi massure', atau laoang ${ }^{49}$ atau selleang.

Tradisi massure' merupakan sebuah tradisi kesenian yang mengiringi manuskrip La Galigo, melalui pembacaan teks dengan alunan irama unik tanpa dibarengi dengan alat musik (Wawancara dengan Sudirman, 11-8-2020). Orang yang membacanya disebut passure'. Saat ini tradisi massure masih terdapat di Wajo, walaupun kehadirannya sudah tidak sama seperti dahulu.

Massure' berbeda dengan tradisi kesenian lainnya di masanya sebut saja kecapi. Pembacaan La Galigo atau massure' membutuhkan lingkungan yang tenang, jauh dari keributan. Lain halnya kecapi, di saat permainan berlangsung, para hadirin akan bersorak dan tertawa bersama ketika bertepatan pada momen yang mereka senangi. Ketika sure' Galigo mulai dilantunkan para hadirin akan diam dan tenang mendengarkan dengan seksama lantunan kisah yang terdapat dalam sure'. Hal ini terjadi karena mereka meyakini bahwasanya pembacaan La Galigo itu

${ }^{47}$ Pudentia Maria PS Suniarti, Metodologi Kajian Tradisi Lisan (Jakarta: Yayasan Obor Indonesia, 2015).

${ }^{48}$ Toa, La Galigo Menurut Manuskrip NBG 188 Edisi Kedua Jilid I.

${ }^{49}$ Arung Pancana Toa, I Lagaligo: Menurut Manuskrip NBG 188, 1st ed. (Jakarta: Djambatan, 1995). 
bukanlah kesenian biasa namun sebuah cerita tentang asal usul mereka di tanah Bugis ini. Mereka sangat menghormati tokohtokoh yang terdapat dalam cerita. Seperti Patoto'e (sang pencipta) di Boting Langi', Batara Guru, dan lain-lain. Tradisi Massure' sejatinya menjadi identitas budaya seperti telah dijelaskan Andini Perdana bagi masyarakat Sulawesi secara umum dan juga di Kabupaten Wajo khususnya. Melalui tradisi ini pula menjadi perekat persatuan.

Pembacaan sure' Galigo pada umumnya dilaksanakan pada malam hari. Karena sejatinya massure' membutuhkan suasana yang tenang dan jauh dari hiruk pikuk. Suasana yang tenang mampu menghadirkan konsentrasi passure dan para hadirin dalam menyimak dan memaknai kandungan sure'. Selain itu, masyarakat Bugis yang pada umumnya bertani, akan mengisi hari terangnya dengan bertani di sawah ataupun di kebun, sehingga ketika pembacaan sure' diadakan di siang hari maka selain suasananya ribut juga akan kurang hadirin yang menyaksikannya karena mereka berada di sawah ataupun di kebun. Malam hari, adalah momen yang tepat, dikarenakan momen dimana masyarakat akan beristirahat sambil berkumpul mendengarkan lantunan suara merdu passure.

Ritual pembacaan manuskrip La Galigo pada malam hari selain sebagai hiburan bagi masyarakat, bahwa waktu malam hari juga memiliki kesakralan yang magis ${ }^{50}$ yang dapat menyentuh hati (penyampaian nilai-nilai religi) bagi masyarakat yang mengikuti atau mendengarkan ritual tersebut. Dalam bab Bugis Religion yang termuat dalam buku The Encyclopedia of Religion, karya Mircea Eliade ${ }^{51}$ sebagaimana dikutip Nurhayati Rahman, ${ }^{52}$ bahwa meskipun orang Bugis telah menjadi Muslim dan beriman, tetapi mereka masih mengekalkan sebahagian tradisi yang bersumberkan elemen pra-Islam, seperti Bissu dan kitab suci La Galigo. Lebih lanjut seperti dijelaskan Andini Galigo."

${ }^{50}$ Rahman, "Agama, Tradisi Dan Kesenian Dalam Manuskrip La

${ }^{51}$ Mircea (ed) Eliade, Bugis Religion DLM The Encyclopedia of Religion (New York: MC. Millan, 1983). Galigo."

${ }^{52}$ Rahman, "Agama, Tradisi Dan Kesenian Dalam Manuskrip La 
Perdana bahwa manuskrip La Galigo, selain berfungsi sebagai sarana penyampai tradisi keagamaan, juga merupakan alat pemersatu bagi masyarakat Bugis, Makassar, Selayar, dan Massenrempulu serta sebagai identitas mereka. ${ }^{53}$

Sure' Galigo tidak serta merta dibaca oleh siapapun orang yang ingin membacanya. Di samping kemahiran membaca lontara' yang merupakan syarat utama dikarenakan sure' Galigo bertuliskan huruf lontaraq', juga untuk memahami maksud dan kandungan yang terdapat dalam sure'. Sejatinya, La Galigo tersusun dengan menggunakan bahasa sastra, bahasa Bugis kuno, sehingga tidak mudah dipahami oleh orang awam walaupun mereka adalah orang Bugis asli. Perlu ketelatenan dalam mempelajari bahasa La Galigo. Selain itu, suara merdu juga menjadi syarat dalam membaca sure' Galigo, karena pembacaan ini membutuhkan waktu yang lama dan tidak dibarengi dengan alat musik. Tanpa suara yang mendukung membuat para hadirin tidak akan betah tinggal lama untuk mendengarnya dengan seksama. Kepiawaian para passure' dalam melantunkan sure' Galigo mampu membuat para hadirin larut dalam keheningan menyimak secara seksama dan bertahan semalam suntuk untuk mendengarkan lantunan sure' Galigo.

Merupakan suatu kebahagiaan bagi masyarakat Wajo, meskipun saat ini passure' di Wajo pada umumnya telah sepu (tua), namun kini masih dapat dijumpai di lingkungan Buloe, Kecamatan Maniangpajo, Kabupaten Wajo. Setidaknya di Wajo masih terdapat tiga generasi passure', yaitu Indo Masse' (Ibu), Indo Wero (anak) dan Rahmadani (cucu), sehingga kekhawatiran akan punahnya salah satu budaya Wajo ini masih dapat terbendung.

\section{Proses pelaksanaan Tradisi Massure'}

Sebagai wujud rasa syukur atau sebagai harapan akan diberi kelancaran dalam hajatannya, masyarakat Bugis pada masa lalu akan melaksanakan tradisi massure'. Masyarakat yang berhajat untuk melaksanakan tradisi massure' membersamai hajatan lainnya, terlebih dahulu akan menghubungi passure' yang akan La Galigo."

${ }^{53}$ Perdana, "La Galigo Identitas Budaya Sulawesi Selatan Di Museum 
diundangnya. Ia meminta kesediaan passure' untuk melantunkan sure' Galigo dalam hajatannya (wawancara dengan Wa'Jelli, 89-2020).

Berdasarkan dari pemaparan yang diperoleh dari ibu Dauleng, ketika beliau diundang untuk membacakan sure' di rumah warga, maka pemilik hajatan akan menyediakan abbare' tudang yang nantinya akan diantarkan ke rumahnya setelah beliau massure'. Pemberian Abbare' tudang berupa beras 4 liter, buah kelapa 1 biji, buah pisang 1 sisir, telur dan pallise'. Abbare' tudang ini dimaksudkan sebagai harapan keselamatan kedua belah pihak (pemilik hajatan dan passure') (Wawancara dengan Dauleng, 1-9-2020). Simbolisasi tersebut, bagi masyarakat Sulawesi pada umumnya merupakan simbol kemakmuran. Gambaran beras $^{54}$ (padi) merupakan lambang kemakmuran bagi masyarakat Sulawesi. ${ }^{55}$ Begitu pula dengan kelapa ${ }^{56}$ (kopra $^{57}$ ), pisang, telur dan pallise merupakan hasil bumi masyarakat pulau Sulawesi yang patut disyukuri sebagai anugerah dari Tuhan Yang Maha Kuasa, baik dari hasil persawahan maupun perkebunan.

Manuskrip I Lagaligo atau sure' selleang/sure' Galigo digunakan pada saat-saat tertentu melalui tradisi Massure'. Pada awalnya, tradisi massure' dilaksanakan di setiap momen-momen tertentu oleh seluruh masyarakat Bugis. Hal ini dikarenakan ma-

${ }^{54}$ Adil Akbar, "Perdagangan Beras Di Sulawesi Selatan 1947-1956," PATTINGALLOANG Adalah Jurnal Pemikiran, Pendidikan Dan Penelitian Kesejarahan 3, no. 2 (2016): 1689-99, https://ojs.unm.ac.id/pattingalloang/ article/view/7092/pdf_27.

${ }^{55}$ M. Zulham, "Makna Simbol Tari Paduppa (Tari Selamat Datang) Kota Palopo," Jurnal Onoma: Pendidikan, Bahasa, Dan Sastra 3, no. 2 (2017): 157-72, https://journal.uncp.ac.id/index.php/onoma/article/view/916.

${ }^{56}$ Chintya Stefanny et. all Anis, "Analisis Pengelolaan Rantai Pasok Tepung Kelapa Pada Pt. XYZ Di Sulawesi Utara," Agri-Sosio Ekonomi Unsrat 13, no. 1 (2017): 81-88, https://ejournal.unsrat.ac.id/index.php/ jisep/ article/view/14922/14479.

${ }^{57}$ Pertiwi P Nugraheni, Robby J Kumaat, and Dennij Mandeij, “Analisis Determinan Ekspor Sulawesi Utara Ke Negara-Negara Tujuan Ekspor Periode 2012-2018," JURNAL EMBA: JJurnal Riset Ekonomi, Manajemen, Bisnis Dan Akuntansi 9, no. 2 (2021): 176-86, https://ejournal.unsrat.ac.id/ index.php/emba/article/view/33335/31530. 
sih banyaknya passure' dan salinan sure' Galigo masih mudah ditemukan di tengah-tengah masyarakat. Munculnya gerakan Darul Islam/Tentara Islam Indonesia (DI/TII) di Sulawesi Selatan yang dipimpin oleh Qahar Muzakkar ${ }^{58}$ pada tahun 19501965 menyebabkan banyaknya sure' Galigo yang dibakar oleh massa. Praktik-Praktik budaya yang tidak sesuai dengan hukum Islam semuanya dibakar saat itu, sehingga setelah peristiwa itu tradisi massure' sudah mulai berkurang dilakukan oleh masyarakat. Lambat laun, hingga hari ini, tradisi ini sudah mulai jarang ditemukan. Hal ini dikarenakan jumlah passure' sudah tidak sebanyak dahulu lagi. Di samping itu, faktor modernitas, dan selera masyarakat berubah, seiring perkembangan waktu. Saat ini, tradisi kesenian massure' tergantikan oleh musik elekton, karaoke, dan main domino. Meski demikian, masyarakat Bugis yang menganut kepercayaan To Riolo yaitu Tolotang masih tetap memelihara tradisi ini hingga saat ini.

Tradisi massure' oleh masyarakat Bugis di Wajo dilaksanakan bersamaan dengan acara-acara seperti penjelasan berikut:

\section{Maddoja bine (ritual menidurkan benih padi)}

Maddoja bine merupakan salah satu ritual masyarakat Bugis di bidang pertanian. Ritual ini merupakan salah satu tradisi La Galigo yang dilakukan oleh petani Bugis. ${ }^{59}$ Secara etimologi, kata maddoja adalah bahasa Bugis yang mengandung arti begadang, terjaga, tidak tidur. Kata bine mengandung arti benih. Tradisi maddoja bine merupakan ritual yang dilakukan oleh masyarakat Bugis dengan berjaga di malam hari menunggui benih padi yang sedang diperam, yang kemudian akan disebar di sawah keesokan harinya. ${ }^{60}$ Ritual ini telah dilaksanakan secara turun

${ }^{58}$ Eka et. al Wulandari, “Aktivitas Gerombolan DI/TII Dan Dampaknya Terhadap," PATTINGALLOANG Jurnal Pemikiran, Pendidikan Dan Penelitian Kesejarahan 7, no. 2 (2020): 160-71, https://doi.org/ https://doi.org/ 10.26858/jp.v7i2.13725.

${ }^{59}$ Andi Sulkarnaen, "Kelanjutan Tradisi Lisan Maddoja Bine Dalam Konteks Perubahan Sosial Masyarakat Bugis," Masyarakat Indonesia 43, no. 2 (2018): 269-83, https://doi.org/10.14203/JMI.V43I2.743.

${ }^{60}$ Sulkarnaen. 
temurun sejak nenek moyang dahulu sampai saat sekarang ini. ${ }^{61}$ Ritual ini dilaksanakan dengan harapan padi yang ditanam akan tumbuh subur, jauh dari hama dan hasil panennya kelak akan melimpah ruah. Oleh karena itu, para petani tidak tidur dan mengikuti tradisi massure', yaitu pembacaan sure' Galigo.

Tradisi massure' di acara maddoja bine dilaksanakan pada malam hari sebelum benih padi tersebut di tabur di sawah keesokan harinya. Karena pada waktu malam, jauh dari suara bising sehingga suara dari passure' jelas terdengar. Berbeda halnya jika siang hari, tidak bisa dipungkiri untuk bebas dari suara bising yang ada (Wawancara dengan Wa' Jelli, 13-8-2020). Tradisi ini sejatinya dapat menjadi hiburan bagi masyarakat yang akan berjaga semalam suntuk, namun terlepas dari itu, tradisi ini juga menjadi media untuk menyampaikan ilmu dan berbagai nasehat dari orang tua. Dalam pandangan Saharudin, ${ }^{62}$ ritual penyemaian bibit padi (termasuk di Sulawesi) adalah bentuk kesadaran pandangan kultural-keagamaan masyarakat setempat dengan menggabungkan pengetahuan lokal dan pengetahuan keagamaan (ajaran sufistik, seperti yang terepresentasikan pada mantra menanam padi dan konsep pare anak iwoq ' padi yatimpiatu' dalam pare pemol' padi pemula/penanda') sebagai wujud kesadaran tentang Wujud Tertinggi dan kosmos.

Ritual ini, sebagaimana kepercayaan masyarakat Bugis dahulu merupakan penghormatan kepada Sangiang Serri (sang dewi padi). Dewi Sri merupakan lambang kesuburan dan kemakmuran bagi manusia. Kepergian Sangiang Serri keesokan harinya diharapkan akan segera kembali saat panen tiba dalam kondisi yang menggembirakan. Petani itu membebaskannya dan berdoa agar Sangiang Serri selamat, sehat, dan subur, dan akan kembali dalam kelimpahan dalam waktu yang tidak lama lagi. Tradisi massure' bermaksud mengingatkan Sangiang Serri akan niat diutusnya ke dunia untuk memenuhi amanah menjadi

${ }^{61}$ Muhammad Yani, "NilaiPendidikan Dalam Ritual Massureq Meong Palo Karella'e Pada Upacara Maddoja Bine Di Desa Leworeng Kecamatan Donri-Donri Kabupaten Soppeng" (Universitas Islam Negeri Makassar, 2018).

${ }^{62}$ Saharudin, "Ritual Domestikasi Padi Lokal Dalam Budaya Sasak Lombok," Jurnal SMaRT 7, no. 2 (2021). 
sumber energi bagi kehidupan manusia. Di sisi lain, Sangiang Serri juga meminta agar diperlakukan dengan baik dan mengingatkan masyarakat untuk selalu menjaga kerukunan sosial di antara mereka. Oleh karena itu Sangiang Serri hanya akan memberikan dirinya pada petani yang memperlakukannya dengan baik. ${ }^{63}$

Dalam ritual maddoja bine, passure' akan membacakan sure' Galigo yang bertemakan petuah dan perjalanan Meong Palo Karellae. Kisah ini menceritakan tentang migrasi Sangiang Serri dan pengikutnya ke beberapa negara Bugis untuk mencari orang-orang yang berbudi luhur dan bagaimana berperilaku dengan mereka. Meong palo karella'e yang artinya kucing yang memiliki banyak warna bulu yaitu kucing yang bergaris merah. Dilihat dari samping, kucing itu tampak merah. Sebaliknya bila kucing dilihat dari depan warna dominannya hitam, selama ini di antara suku Bugis terdapat kucing yang memiliki tiga warna yaitu belang merah atau hitam keloreng-lorengan, dan jantan dianggap mempunyai dimensi kedewataan, sebagai makhluk suci dan keramat. ${ }^{64}$

Adapun makanan yang pada umumnya disediakan dalam tradisi massure' pada acara mappano bine adalah songkolo dan pallise'. Songkolo' adalah beras ketan yang dimasak, adapun pallise' adalah kelapa parut yang dicampur dengan gula merah lalu dimasak. Makanan yang disediakan ini kemudian akan dimakan bersama keesokan harinya setelah menabur benih padi di sawah (Wawancara dengan Wa'Jelli, 8-9-2020).

Sejatinya, sure' Galigo dibacakan melalui tradisi massure', namun saat ini sebahagian masyarakat di Wajo sudah mulai meninggalkan tradisi ini, karena sulit menjangkau passure'dan kemampuan membaca aksara lontara' pun sudah berkurang, sehingga perlakuan terhadap sure' Galigo ini adalah dengan meletakkannya diantara sesajian yang disiapkan. Dari penuturan Ibu Dinggi', ketika hendak mengadakan acara maddoja bine dan mappano bine, maka sebelum ia ke sawah membawa benih padi

\footnotetext{
${ }^{63}$ Sulkarnaen, "Kelanjutan Tradisi Lisan Maddoja Bine Dalam Konteks Perubahan Sosial Masyarakat Bugis."

${ }^{64}$ Nonci, Meong Palo Karellae (Makassar: CV Aksara, 2006).
} 
yang akan ditanam, sure' tersebut ia letakkan di samping benih yang akan ditabur bersama dengan sesajian yang telah disiapkan yang nantinya akan dimakan bersama setelah proses penanaman benih padi selesai (Wawancara dengan Dinggi, 27-8-2020).

Sesaji dalam masyarakat Indonesia, masih dilakukan oleh sebagian masyarakat sebagai bentuk penghormatan kepada nenek moyang, termasuk oleh masyarakat Bugis. Menurut Muwafiqillah, ${ }^{65}$ ritual kawit dan wiwit memiliki makna, bahwa (1) proses ritual kawit dan wiwit dimulai dari penentuan hari baik, mempersiapkan sesaji, dan pelaksanaan ritual di sawah oleh dukun kawit dengan beberapa tahapan yang dilakukan salah satunya meletakkan sesaji di pojok sawah sambil membaca mantra; (2) makna simbolik dalam ritual ini yakni dari pemilihan sesaji yang digunakan mengandung banyak makna yaitu sebagai simbol pengharapan masyarakat. Misalnya dengan meletakkan sesaji di pojok sawah berharap tanaman padi berjalan dengan lancar dan mendapatkan hasil yang berlimpah.

\section{Mappenre tojang (Akikahan)}

Kehadiran seorang anak dalam sebuah keluarga merupakan momen yang sangat membahagiakan. Menjadi sunnah muakkadah bagi orang tua untuk mengadakan acara akikah bagi anak yang baru lahir, sebagai wujud syukur kepada Allah Swt. Upacara ini sudah sangat masyhur ${ }^{66}$ termasuk masyarakat Bugis. Dalam upacara mappenre tojang masyarakat Bugis dahulu akan dilakukan bersama dengan tradisi massure' di malam harinya. Namun saat ini, hanya sebahagian kecil masyarakat Bugis Wajo yang melaksanakan tradisi ini.

${ }^{65}$ M. Muwafiqillah \& Oksiana Jatiningsih AL Hasani, "Makna Simbolik Dalam Ritual Kawit Dan Wiwit Pada Masyarakat Pertanian Di Desa Ngasemlemahbang Kecamatan Ngimbang Kabupaten Lamongan," Kajian Moral Dan Kewarganegaraan 3, no. 2 (2014), https://jurnalmahasiswa. unesa.ac.id/index.php/jurnal-pendidikan-kewarganegaraa/article/view/9408.

${ }^{66}$ Nafilatul Ilmiyyah, "Pemahaman Dan Implementasi Hadits-Hadits Aqiqah Pada Masyarakat Desa Kauman Kota Kudus," Journal of Chemical Information and Modeling 53, no. 9 (2016), https://doi.org/https://doi.org/ 10.1017/CBO9781107415324.004. 
Dalam acara mappenre' tojang, tradisi massure' dilaksanakan pada malam hari acara akikah. Masyarakat yang mempunyai hajat akan mengundang passure' untuk membacakan manuskrip La Galigo atau sure' selleang lalu itu akan didengarkan oleh masyarakat yang hadir pada acara tersebut. Tidak ada makanan wajib yang menjadi persyaratan dalam pelaksanaan tradisi ini, makanan yang disediakan sesuai dengan kesanggupan pemilik hajat (Wawancara dengan Indo Masse, 10-8-2020). Tradisi ini juga dilakukan pada ritual Menre bola baru (naik rumah baru atau menempati rumah baru). Tradisi Massure' yang sejatinya sebagai hiburan masyarakat Bugis dahulu ketika duduk bersama, sehingga tradisi inipun dapat dijumpai pada acara menre bola baru (naik rumah baru). Pada acara ini, tradisi massure' dilaksanakan pada malam pertama di saat memasuki rumah baru.

Pada masa dahulu, pembacaan sure' Galigo dilaksanakan selama semalam suntuk, dimulai setelah shalat magrib sampai menjelang subuh. Sure' akan dibaca oleh beberapa passure' yang diundang. Mereka berganti-gantian, sambung-menyambung membaca sure' hingga menjelang subuh. Berdasar penuturan Ibu Dauleng (Wawancara, 3-9-2020), masyarakat yang menjadikan pembacaan sure' sebagai mata pencahariannya, maka malamnya dijadikan sebagai siang dan siangnya dijadikan sebagai malam, ataupun pembacaannya dengan melihat kehadiran penonton, ketika para hadirin sudah mulai membubarkan diri satu persatu, maka passure' pun akan menyelesaikan bacaannya. Hal ini, sesuai kesepakatan passure' dengan pemilik hajat.

Saat ini, pembacaan sure' Galigo sudah tidak selama dahulu, berhubung passure' yang diundang sudah sepu sehingga kemampuannya untuk membaca lama sudah berkurang. Di samping itu, minat generasi muda untuk mendengarkannya semakin berkurang. Sehingga saat ini, ketika passure' mulai melantunkan sure' Galigo ini hanya memakan waktu tidak lebih dari satu jam (Wawancara dengan Indo Masse, 2-9-2020). 


\section{Tudang penni (pesta malam sebelum akad nikah)}

Acara tudang penni sejatinya adalah persiapan malam sebelum akad nikah dilakukan keesokan harinya. ${ }^{67}$ Saat ini acara tudang penni yang dilakukan oleh masyarakat Bugis muslim meliputi: mappanre temme' (acara khataman Qur'an), mappacci (proses adat pengantin yang mengguna-kan daun pacar atau pacci), mabbarazanji (pembacaan Barzanji). Sebelum adanya, tradisi mabbarazanji, masyarakat Bugis dahulu melakukan sebuah tradisi, yaitu pembacaan sure' Galigo. Namun, saat ini, sudah sangat jarang ditemui, bahkan tradisi massure' ini nyaris tidak ditemui dalam acara tudang penni.

Tradisi massure' dalam acara tudang penni, dilaksanakan pada malam pengantin, yaitu malam dimana akan diadakan akad nikah pada esok harinya. Untuk masyarakat Tolotang, tradisi massure' untuk acara pengantin hanya dilakukan oleh keluarga bangsawan (Wawancara dengan Wa'Jelli, 13-8-2020). Selain keempat upacara yang telah disebutkan sebelumnya, tradisi massure' pun dapat dijumpai ketika masyarakat mempunyai sebuah hajat atau bernadzar. Bernadzar dalam artian, ketika dia menginginkan sesuatu, dan dia berjanji untuk melakukan tradisi massure' setelah hajatnya terpenuhi. Jika hajatnya terpenuhi, maka dia akan berkewajiban untuk menunaikan nazarnya. Ketika dia tidak melakukan tradisi tersebut, maka dia percaya akan datangnya mudharat bagi diri dan keluarganya (Wawancara dengan Dauleng, 3-9-2020).

Upaya untuk melestarikan sure' Galigo masih gencar dilakukan saat ini, sehingga tradisi yang melibatkan sure' Galigo ini akan selalu dilestarikan oleh masyarakat dan pemerintah Wajo, salah satunya yakni tradisi massure. Saat ini, tradisi massure' ini pun dapat dijumpai pada kegiatan festival kebudayaan kabupaten Wajo setiap tahunnya, juga pada acara-acara budaya lainnya di Sulawesi Selatan.

${ }^{67}$ Muh. Rusli, "Reinterpretasi Adat Pernikahan Suku Bugis Sidrap Sulawesi Selatan," KARSA: Jurnal Sosial Dan Budaya Keislaman 20, no. 1 (2001): 2, https://doi.org/https://doi.org/10.19105/karsa.v20i2.45. 


\section{PENUTUP}

Manuskrip La Galigo di Wajo menjadi koleksi pribadi sebahagian masyarakat yang disimpan di rumah masing-masing. Proses pewarisan manuskrip La Galigo yang menjadi koleksi masyarakat di Wajo melalui pewarisan yang berbeda; pertama, pada umumnya manuskrip sure' diperoleh dari nenek moyang yang menjadi koleksi turun temurun keluarga; kedua, diperoleh dari masyarakat untuk dipustakakan; ketiga, proses pewarisan yang diperoleh dari masyarakat yang mempunyai profesi tertentu yang berkaitan dengan manuskrip La Galigo. Seperti passure'.

Pembacaan manuskrip melalui tradisi massure' oleh masyarakat Bugis Wajo, dapat dilakukan melalui berbagai acara atau ritual. Massure' dapat dijumpai pada upacara-upacara masyarakat Bugis seperti maddoja bine (menidurkan benih padi), mappenre' tojang (akikahan), menre' bola baru (naik rumah baru), tudang penni (pesta malam pra akad nikah), dan dalam berbagai festival kebudayaan Wajo. Tradisi massure' merupakan sebuah tradisi kesenian yang mengiringi manuskrip La Galigo, melalui pembacaan teks dengan alunan irama yang unik tanpa diiringi alat musik. Orang yang membacanya disebut passure'. Tradisi ini dapat dijumpai hingga saat ini dalam festival budaya Wajo, juga dalam lingku-ngan perkampungan Masyarakat penganut kepercayaan Tolotang di Ling. Buloe Kabupaten Wajo.

Terdapat beberapa catatan penting, bahwasanya tradisi pembacaan La Galigo (massure') sudah mulai berkurang di kalangan generasi muda. Hadirnya teknologi mengikis secara perlahan eksistensi tradisi ini. Tradisi massure', kini mulai tergantikan dengan musik dangdut atau pop dengan menghadirkan elektone, musik modern lain. Di samping itu, kurangnya minat generasi muda untuk mengenal tradisi ini menjadi salah satu faktor punahnya tradisi ini.

Penelitian ini menawarkan beberapa rekomendasi sebagai bahan kebijakan bagi pemerintah dalam pembangunan di bidang sosial budaya. Pertama, Pemerintah Provinsi Sulawesi Selatan khususnya Dinas Pariwisata dan Budaya, Kementerian Agama Provinsi Sulawesi Selatan, peneliti baik di Perguruan Tinggi Agama Islam maupun peneliti Balai Litbang Agama Makassar, perlu melakukan penelitian lanjutan dan pengembangan yang 
inovatif, sehingga manuskrip La Galigo dapat dikenal secara luas oleh masyarakat Sulawesi Selatan. Kedua, salah satu hal yang dapat dilakukan adalah membuat film animasi, film kartun, buku cerita berbasis manuskrip La Galigo dan manuskrip lainnya, sehingga kekayaan budaya lokal nusantara ini dapat dinikmati generasi muda saat ini baik di Sulawesi khususnya maupun masyarakat Indonesia pada umumnya.

\section{Ucapan Terima Kasih}

Penulis menyampaikan terima kasih atas selesainya penulisan artikel ini. Ungkapan terima kasih penulis sampaikan kepada Kepala Balai Litbang Agama Makassar, Bapak Dr. H. Saprillah, M.Si, yang telah menugaskan penulis dalam melaksanakan penelitian ini. Begitu pula kepada pembimbing Bapak Dr. H. Abdul Kadir M., M.Ag., dan Prof. Dr. H. Idham, M.Pd. Tak lupa pula, penulis menyampaikan terima kasih kepada pihak Pemerintah Provinsi Sulawesi Selatan, Kabupaten Wajo, kepada ketua Yayasan Budaya Wajo Bapak Sudirman Sabang, Ibu Dauleng, Hasmawati yang telah membantu penulis memperoleh data di lokasi penelitian. Selain itu, ucapan terima kasih juga penulis sampaikan kepada koordinator bidang Lektur Balai Litbang Agama Makassar, Abu Muslim, M.H.I dan koordinator penelitian Husnul Fahima Ilyas, MA. Hum. yang turut membantu penulis dalam proses penelitian. Tak lupa pula penulis berterima kasih kepada berbagai pihak yang telah menyumbangkan aspirasi dan bantuannya selama proses berjalannya penelitian ini. 


\section{DAFTAR PUSTAKA}

\section{Buku}

Anonim. Manuskrip Sure' Selleang (Manuskrip La Galigo) Episode: Mammusuna Karaeng Tompo' Sibawa La Galigo, Koleksi Dauleng Di Baru Alau Kec. Tempe Kab. Wajo., n.d.

Anwar, Khairil et. all. Manuskrip Klasik Keagamaan Edisi Bahasa Melayu. Tangerang: CV. Sejahtera Kita, 2009.

Asrullah, Ahmad. "Perancangan Buku Cerita Bergambar Berjudul Sawerigading Dari Cerita Rakyat Manuskrip Kuno 1 La Galigo." Universitas Komputer Indonesia, 2016. http://elib. unikom.ac.id/ gdl.php?mod=browse\&op=rea.

Azra', Azyumardi. Jaringan Ulama Timur Tengah Dan Kepulauan Nusantara Abad XVII \& XVII. Jakarta: Prenada Media Group, 2005.

Baried, Siti Baroroh. Pengantar Filologi. Jakarta: Departemen Pendidikan dan Kebudayaan, 1985.

Eliade, Mircea (ed). Bugis Religion DLM The Encyclopedia of Religion. New York: MC. Millan, 1983.

Enre, Fachruddin Ambo. Ritumpanna Welenrennge. Telaah Filologis Sebuah Episode Sastera Bugis Klassik Galigo. Jakarta: Universitas Indonesia, 1983.

Fathurahman, Oman. Filologi Dan Islam Indonesia. Jakarta: PUSLITBANG Lketur dan Khazanah Keagamaan dan Manajemen Organisasi Badan LITBANG dan DIKLAT Kementerian Agama RI, 2010.

- Filologi Indonesia Teori Dan Metode. Jakarta: Kencana, 2015.

Geertz, Clifford. Agama Jawa Abangan, Santri, Priyayi Dalam Kebudayaan Jawa. Edited by Moh Zaki. Depok: Komunitas Bambu, 2014.

Idham. Katalog Manuskrip Keagamaan. Jakarta: Litbangdiklat Press, 2018. 
Kern, R.A. Catalogus van de Boeginise, Tot de I LagaligoCyclus Behorende Handschriften van Jajasan Matthes (Matthesstichting) Te Makassar (Indonesie. Makassar: Jajasan Matthes, 1954.

Koolhof, Sirtjo. Dutana Sawerigading: Een Scene Uit de I La Galigo. Belanda: Universitas Leiden, 1992.

Kuntowijoyo. Metodologi Sejarah. Yogyakarta: Tiara Wacana, 2003.

Masoweang, Abd Kadir et. al. Katalog 1 Manuskrip Keagamaan Kawasan Timur Indonesia. Makassar: Balai Penelitian dan Pengembangan Agama Makassar, 2015.

Minhaji, Akh. Sejarah Sosial Dalam Studi Islam, Teori, Metodologi, Dan Implementasi. Yogyakarta: Suka Press, 2010.

Muhammad Yani. "NilaiPendidikan Dalam Ritual Massureq Meong Palo Karella'e Pada Upacara Maddoja Bine Di Desa Leworeng Kecamatan Donri-Donri Kabupaten Soppeng." Universitas Islam Negeri Makassar, 2018.

Nonci. Meong Palo Karellae. Makassar: CV Aksara, 2006.

Paeni, Mukhlis. Sejarah Kebudayaan Indonesia; Religi Dan Falsafah. Jakarta: PT Raja Grafindo Persada, 2009.

Pertiwi, Wiwik et al. Kajian Nilai Budaya Manuskrip Kuna Mapalina Sawerigading Ri Saliweng Langi. Jakarta: Direktorat Jenderal Kebudayaan RI, 1998.

Provinsi Sulawesi Selatan. "Deskripsi Daerah Kabupaten Wajo." https://sulselprov.go.id/pages/des_kab/21, 2007.

Rahman, Nurhayati. "Edisi Manuskrip-Manuskrip Bugis." In Direktori Edisi Manuskrip Nusantara, edited by ES Ekajati. Jakarta: Masyarakat Permanuskripan Nusantara-Yayasan Obor Indonesia, 2000.

Makassar: Pusat Studi La Galigo Divisi Ilmu Sosial dan Humaniora Pusat Kegiatan Penelitian Universitas 
Hasanuddin dengan Pemerintah Kabupaten Barru, 2003.

Suniarti, Pudentia Maria PS. Metodologi Kajian Tradisi Lisan. Jakarta: Yayasan Obor Indonesia, 2015.

Toa, Arung Pancana. I Lagaligo: Menurut Manuskrip NBG 188. 1st ed. Jakarta: Djambatan, 1995.

—. La Galigo Menurut Manuskrip NBG 188 Edisi Kedua Jilid I. Edited by fachruddin Ambo Enre. Jakarta: Yayasan Obor Indonesia, Yayasan La Galige, KITLV, 2017

\section{Jurnal Ilmiah}

Abidin, Andi Zainal. "The I La Galigo Epic Cycle Of South Celebes And Its Diffusion." JSTOR 53, no. 17 (1974): 16169. https:// www.jstor.org/stable/3350778? seq=1.

Akbar, Adil. "Perdagangan Beras Di Sulawesi Selatan 19471956." PATTINGALLOANG Adalah Jurnal Pemikiran, Pendidikan Dan Penelitian Kesejarahan 3, no. 2 (2016): 1689-99.https://ojs. unm.ac.id/pattingalloang/article/view/70 92/pdf_27.

Andini Perdana. "Nilai Budaya Manuskrip La Galigo Dan Perahu Pinisi di Museum Untuk Generasi Milenial." Walasuji: Jurnal Sejarah Dan Budaya 11, no. 1 (2020). https://doi.org/https: //doi.org/10.36869/wjsb.v11i1.72.

Anis, Chintya Stefanny et. all. "Analisis Pengelolaan Rantai Pasok Tepung Kelapa Pada Pt. XYZ Di Sulawesi Utara." Agri-Sosio Ekonomi Unsrat 13, no. 1 (2017): 81-88. https://ejournal.

unsrat.ac.id/index.php/jisep/article/view/14922/14479

Bachmid, Gayda. 'Kitab 'Barzanji' Dalam Perspektif Masyarakat Muslim di Manado, Sulawesi Utara." Lektur Keagamaan 12, no. 2 (2014): 419-40. https://doi.org/https:// doi.org/ $10.31291 / \mathrm{j} 1 \mathrm{k} . \mathrm{v} 12 \mathrm{i} 2.42$.

Hasani, M. Muwafiqillah \& Oksiana Jatiningsih AL. "Makna Simbolik Dalam Ritual Kawit Dan Wiwit Pada Masyarakat Pertanian Di Desa Ngasemlemahbang Kecamatan Ngimbang 
Kabupaten Lamongan." Kajian Moral Dan Kewarganegaraan3,no.2 (2014). https://jurnalmahasiswa.unesa.ac.id/ index. php/jurnal-pendidikan-kewarganegaraa/article/view/ 9408.

Hudzaifah, Adiatma. "Peran Puik-Puik Dalam Kesenian Gandrang Makassar." Dewa Ruci: Jurnal Pengkajian Dan Penciptaan Seni 15, no. 2 (2020): 101-9. https://doi.org/ 10.33153/dewaruci. v15i2.2699.

Macknight, Campbell. “'I La Galigo': State Theatre, Melbourne International Arts Festival 19-23 October 2006." Jurnal RIMA: Review of Indonesian and Malaysian Affairs 40, no. 2 (2006): 1-152.

Mustari. "Perlawanan Gender Dalam Manuskrip Klasik Keagama-an Bugis Kasus Lontaraq Sitti Rabiatul Awwaliya." Jurnal Lektur Keagamaan 5, no. 2 (2007): 15982.

Nafilatul Ilmiyyah. "Pemahaman dan Implementasi HaditsHadits Aqiqah Pada Masyarakat Desa Kauman Kota Kudus." Journal of Chemical Information and Modeling 53, no. 9 (2016). https://doi.org/https://doi.org/10.1017/ CBO9 781107415324.004.

Nugraheni, Pertiwi P, Robby J Kumaat, and Dennij Mandeij. "Analisis Determinan Ekspor Sulawesi Utara Ke NegaraNegara Tujuan Ekspor Periode 2012-2018." JURNAL EMBA: JJurnal Riset Ekonomi, Manajemen, Bisnis Dan Akuntansi 9, no. 2 (2021): 176-86. https://ejournal. unsrat. ac.id/index.php/emba/article/ view/ 33335/31530.

Nurnanigsih. "Asimilasi Lontara Pangadereng Dan Syariat Islam : Pola Perilaku Masyarakat Bugis-Wajo." Al-Tahrir: Jurnal Pemikiran Islam 15, no. 1 (2015): 21. https://doi.org/ 10.21154/al-tahrir. v15i1.168.

Nurnaningsih. "Rekonstruksi Falsafah Bugis Dalam Pembinaan Karakter: Kajian Manuskrip Paaseng Toriolo Tellumpoccoe." Jurnal Lektur Keagamaan 13, no. 2 (2015): 393. https://doi.org/ 10.31291/jlk.v13i2.232. 
Perdana, Andini. "La Galigo Identitas Budaya Sulawesi Selatan

Di Museum La Galigo." Pangadereng: Jurnal Hasil Penelitian Ilmu Sosial Dan Humaniora 5, no. 1 (2019): 11632. https://doi.org/ 10.36869/.v5i1.16.

Rahman, Nurhayati. "Agama, Tradisi dan Kesenian Dalam Manuskrip La Galigo.” Jurnal Sari (ATMA) 26 (2008): 21320.

Rusli, Muh. "Reinterpretasi Adat Pernikahan Suku Bugis Sidrap Sulawesi Selatan." KARSA: Jurnal Sosial Dan Budaya Keislaman 20, no. 1 (2001): 2. https://doi.org/https:// doi. org/10.19105/karsa.v20i2.45.

Saharudin. "Ritual Domestikasi Padi Lokal Dalam Budaya SasakLombok." Jurnal SMaRT 7, no. 2 (2021).

Sulkarnaen, Andi. "Kelanjutan Tradisi Lisan Maddoja Bine Dalam Konteks Perubahan Sosial Masyarakat Bugis." Masyarakat Indonesia 43, no. 2 (2018): 269-83. https:// doi.org/10.14203/JMI.V43I2.743.

Tungkagi, Donald Qomaidiansyah. "Islam Di Bolaang Mongondow Utara, Sulawesi Utara: Dinamika Islamisasi Di Kerajaan Kaidipang Besar Dan Bintauna Abad Ke-7-19 M.” Jurnal Lektur Keagamaan 17, no. 2 (2019): 461-500. https://doi.org/https://doi.org/10.31291/j1k.v17i2.747.

Winoto, Yunus. "Membangun Kesadaran Masyarakat Sumedang Dalam Melestarikan Warisan Budaya (Sebuah Kajian Fenomenologis Tentang Pengalaman Pustakawan Perpustakaan Yayasan Pangerang Sumedang Dalam Melakukan Kegiatan Pelestarian Buku 'Babad Sumedang').' LIBRARIA: Jurnal Perpustakaan 6, no. 1 (2018): 83-110. https:// doi.org/http://dx.doi.org/10.21043/libraria.v6i1.3891.

Wulandari, Eka et. al. "Aktivitas Gerombolan DI / TII Dan Dampaknya Terhadap." PATTINGALLOANG Jurnal Pemikiran, Pendidikan Dan Penelitian Kesejarahan 7, no. 2 (2020): 160-71. https://doi.org/https://doi.org/ 10.26858/ jp.v7i2.13725. 
Yuwana Sudikan, Setya. "Pendekatan Interdisipliner, Multidisipliner, dan Transdisipliner Dalam Studi Sastra." Paramasastra: Jurnal Ilmiah Bahasa Sastra dan Pembelajarannya 2, no.1 (2015): 6870. https://doi.org/http:// dx.doi.org/ 10.26740/parama. v2n1. p\%25p.

Zulfikar, Achmad. "Internalisasi Nilai-Nilai Sastra I La Galigo Dalam Forum Internasional." In Kongres Internasional II Bahasa-Bahasa Daerah Sulawesi Selatan Tahun 2012, 112. Sulawesi Selatan: Balai Bahasa Provinsi Sulawesi Selatan dan Provinsi Sulawesi Barat, 2017. https://doi.org/ 10.31227/osf.io/p6sh7.

Zulham, M. "Makna Simbol Tari Paduppa (Tari Selamat Datang) Kota Palopo." Jurnal Onoma: Pendidikan, Bahasa, Dan

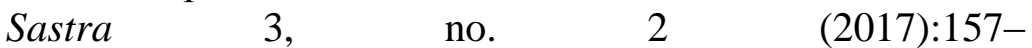
72.https://journal.uncp.ac.id/index.php/onoma/ article/view/916.

\section{Website}

Karnadi, Pudentia Maria Purenti Sri Suniarti. "Mak Yong: Hakikat Dan Proses Penciptaan Kelisanan." Universitas Indonesia, 2000. http://lib.ui.ac.id/detail?id= 74091\&lokasi= lokal.

Matthes, Benjamin Frederik. De Makassaarsche En Boeginesche Kotika's. Gravenhage: martinus Nijhoff, 1875. https://opac. perpusnas.go.id/DetailOpac.aspx $? \mathrm{id}=602396$. 